\title{
Generalized gene transfer by virus-like particles from marine bacteria
}

\author{
Hiroshi X. Chiura* \\ Institut für Medizinische Biologie, Abt. Allgemeine Mikrobiologie, Universität Wien, Währingerstr. 17/2, A-1090 Wien, Austria
}

\begin{abstract}
Spontaneous VLP (virus-like particle) production and VLP-mediated gene transfer into Escherichia coli AB1157 as recipient was demonstrated. Five marine isolates (Alc 096, Alc 233, Alc 252, Agrobacterium kieliense and Flavobacterium sp. 11604) were investigated for their potential to produce VLP as well as for the gene transfer capability of these VLPs to the $E$. coli recipient. These strains are classified as ubiquinone-10-possessing marine bacteria (Q10MB) in the 16s-rRNA Superfamily IV VLPs were obtained from $100 \mathrm{~h}$ cultured broth of all strains examined. VLP-host ratio after $100 \mathrm{~h}$ growth culture was: Alc 233, 1.54; Alc 252, 1.26; Alc 096, 1.06; Flavobacterium sp. 11604, 0.69; and A. kieliense, 0.06 . These ratios were smaller than those found in the marine environment. However, the spontaneously produced VLP number can be considered as high because the reported numbers are relatively low from coliphage $\lambda(0.005)$ and phage $\mathrm{Mu}(\sim 0.0001)$. VLP-mediated gene transfer was examined using an auxotrophic mutant of $E$. coli (AB1157) with 4 amino acid deficiencies (leu, pro, his, arg) as recipient at multiplicity of infection (MOI) of 0.1. Through this treatment, VLPs showed lethal effect on the recipient. The survival rate of control was: Alc 096, 7\%; Alc 252, 8\%; A. kieliense, $17 \%$; Flavobacterium sp. I1604, 31\%; and Alc 233, 40\%. At the same time, all the purified VLPs derived from these 5 strains successfully transferred genes to rescue genetic defects of the recipient. Overall average efficiency of VLP-mediated gene transfer at MOI of 0.1 was estimated to be between $2.62 \times 10^{-3}$ and $3.58 \times 10^{-5}$ per VLP particle. Loci of employed genetic markers were dispersed on the $E$. coli chromosome with mutual distance of 121, 1154, 1397 and $364 \mathrm{~kb}$ between them. Since VLPs from different sources showed similar gene transfer efficiency in respect to the genetic marker rescued, it is suggested that VLPS from Q10MB transferred genes as generalized transduction. These results indicate that the VLPs produced by certain marine bacteria may be an important element for both non-specific generalized horizontal gene transfer towards a broad range of bacterial hosts and population control in the marine environment.
\end{abstract}

KEY WORDS: Virus-like particles (VLPS) - Generalized transducing ability · Horizontal gene transfer · Transductants - Bactericidal effect - Marine bacteria - Ubiquinone-10

\section{INTRODUCTION}

Viruses (or virus-like particles, VLPs) in aquatic environments are acknowledged to be general constituents of the ecosystem (Bergh et al. 1989, Børsheim et al. 1990, Ogunseitan et al. 1990, Hara et al. 1991, Wommack et al. 1992, Børsheim 1993, Fuhrman \& Suttle 1993, Paul et al. 1993, Mathias et al. 1995). Major pos-

\footnotetext{
- Correspondence address: Department of Biology, Division of Natural Sciences, International Christian University, 3-10-2 Osawa, Mitaka, Tokyo 181, Japan. E-mail: chiura@icu.ac.jp
}

tulated roles for phages (VLPs) in the aquatic environment are bacterial population control and gene transfer in situ (Miller \& Sayler 1992). Recently, the possible functions of viruses or VLPs in controlling bacterial mortality and the reduction of microbial production have been reported (Proctor \& Fuhrman 1990, Suttle et al. 1990, Maruyama et al. 1993, Nagasaki et al. 1993, Suttle \& Chan 1994, Weinbauer \& Peduzzi 1994, Hennes \& Simon 1995, Mathias et al. 1995). Known modes of gene transfer are plasmid-mediated conjugation, genetic transformation, and phage-mediated transduction (Gauthier \& Breittmayer 1990, Ambile-Cuevas 
\& Chicurel 1992). Horizontal gene transfer is assumed to be important for the evolution and genetic diversity of natural microbial communities and is therefore an important phenomenon to be understood (Saye \& Miller 1989). However, it is well known that bacterial cells generally restrict their acceptance of foreign genetic materials (Streips \& Yasbin 1991). Although 'trans-kingdom' gene transfer has been reported (Stachel et al. 1986, Heineman \& Sprague 1989, Zambryski et al. 1989, Sikorski et al. 1990), the occurrence of gene transfer between different bacterial species and genera in nature is so far known to be mediated by plasmids (Don \& Pemberton 1981, Brisson-Noel et al. 1988, Schafer et al. 1990, Mazodier \& Davies 1991). Promiscuous gene transfer, when observed, is predominantly mediated by plasmids (Lorenz \& Wackernagel 1994). Hence, virus-mediated gene transfer (transduction) has been considered to be a factor of minor importance for genelic diversity and evolution in the nalural microbial community. Only recently has transduction become apparent as a potentially important means for the redistribution of genetic information in natural microbial habitats (Miller \& Sayler 1992, Ripp et al. 1994, Schicklmaier \& Schmieger 1995).

During a study on properties of marine bacterial endonucleases (Chiura et al. 1988, 1992a, b), excretion of VLPs bearing nucleic acid into the broth was incidentally observed from the strains used for the investigation (Chiura \& Takagi 1994. Chiura et al. 1995). These rod-shaped marine strains were classified as members of the Superfamily IV by 16 s-rRNA analysis (De Ley 1991), and by having ubiquinone-10 as the sole component of coenzyme $\mathrm{Q}$ (abbreviated as ubiquinone10-possessing marine bacteria: Q10MB). Spontaneous releases of VLPs from eubacterial strains have been seldom reported, and are considered as being quite unusual, although some similar phenomena in archaeand photosynthetic bacteria were mentioned by Reiter et al. (1987), Shaefer et al. (1974), Solioz \& Marrs (1977), Wall et al. (1975), Wood et al. (1989), and Schleper et al. (1992). Recently, a high occurrence of spontaneously induced temperate phages together with high frequency of a generalized transducing trait in natural isolates of Salmonella have been reported (Schicklmaier \& Schmieger 1995). The authors pointed out that the potential for phage-mediated gene transfer may be much higher than expected.

VLPs from Flavobacterium sp. 11604 belonging to Q10MB have been shown to mediate chromosomal gene transfer in Escherichia coli with lethal effects (Chiura et al. 1995). Hence, VLPs derived from several marine bacteria which were not related to recipient $E$. coli, at least at the family level, were investigated. The purpose of this study was to determine if VLPs derived from some Q10MB are on the one hand capable of controlling bacterial population diversity and on the other capable of mediating gene transfer.

\section{MATERIALS AND METHODS}

Bacterial strains as the source of VLPs and gene transfer recipient bacteria. Aerobic Gram-negative marine eubacterial strains of Agrobacterium kieliense, Alc 096, Alc 233, Alc 252 and Flavobacterium sp. I1604 were used in this study as sources of VLPs. Sampling and isolation sites are summarized in Table 1. A. kieliense IAM 12618 was obtained from the IAM Culture Collection, Center for Cellular and Molecular Research, Institute of Molecular and Cellular Biosciences, the University of Tokyo, Bunkyo-ku, Tokyo, Japan. This strain is classified in the rRNA Superfamily IV (the $\alpha$-subdivision) in the class Proteobacteria, however there are no known close relatives (De Ley 1991). Rüger \& Höfle (1992) also indicated that the strain could not be placed in a subdivision of the genus Agrobacterium. Strains Alc 096, Alc 233, and Alc 252 were obtained from M. Akagawa-Matsushita, Minaikyushu University. Based on rRNA-DNA hybridization experiments (Akagawa-Matsushita pers. comm.), Alc 096 had been shown to have no relationship to any members of rRNA Superfamilies I, II, III and IV, and therefore its phylogenetic position is not yet determined. The strains Alc 233 and Alc 252 have been shown to belong to the rRNA Superfamily IV, however they are not closely related to each other and there are

Table i Übiquinone-10-possessing marne bacteriai. (Q10iviB) strains, sampling site, materiai and source (year). They are Gramnegative, rod-shaped, aerobic, marine eubacteria. 'Alc' numbers are arbitrary, given by Akagawa-Matsushita. Although their phylogenic position was determined using 16s-rRNA analysis (De Ley 1991), they do not have strain nomenclature

\begin{tabular}{|llll}
\hline Strain & Sampling site & Material & Source \\
\hline Agrobacterium kieliense & Kiel Bay, Baltic Sea & Seawater & M. Akagawa-Matsushita (1988) \\
Alc 096 & Iou-Tou Is., Pacific Ocean & Seawater & M. Akagawa-Matsushita (1988) \\
Alc 233 & Chiba, Japan & Seaweed & M. Akagawa-Matsushita (1988) \\
Alc 252 & Kanagawa, Japan & Seaweed & M. Akagawa-Matsushita (1988) \\
Flavobacterium sp. 11604 & Indian Ocean & Seawater & U. Simidu (1983) \\
\hline
\end{tabular}


no known close relatives (Akagawa-Matsushita pers. comm.). As Escherichia coli belongs to rRNA Superfamily I ( $\gamma$-subdivision) in the class Proteobacteria (De Ley 1991), these 5 strains are not related to $E$. coli, at least at the family level. Flavobacterium sp. I1604 was donated from the natural isolate culture collection of the Ocean Research Institute, the University of Tokyo, Nakano-ku, Tokyo, Japan. The strain Flavobacterium sp. 11604 has ubiquinone-10 (Q10) and its mole percent guanine plus cytosine content (mol\% $\mathrm{G}+\mathrm{C}$ ) in DNA is $65.2 \%$ (Akagawa-Matsushita pers. comm.). This strain is probably not a member of the Flavobacterium because of its lack of menaquinones. Although its phylogenetic position is still unknown, the presence of Q10 suggests that it should be assigned to the rRNA Superfamily IV in the class Proteobacteria (abbreviated as ubiquinone-10-possessing marine bacteria, Q10MB). All the species in the rRNA Superfamily IV have Q10 as coenzyme Q (CoQ) with few exceptions (Collins \& Jones 1981, Yokota et al. 1992).

Escherichia coli AB1157 was obtained from the National Institute of Genetics (Shizuoka, Japan), and has the following genetic features: F-; thr-1 leuB6 thi-1 lac $Y 1$ galk2 ara-14 xyl-5 mtl-1 proA2 his-4 argE3 rplsL31 tsx-33 supE44. E. coli AB1157 was used as the recipient bacterium for VLP-mediated gene transfer.

Culture conditions. PPES II [modified seawater broth: $0.1 \%$ proteose peptone no. $3,0.2 \%$ polypeptone, $0.1 \%$ yeast extract and $0.1 \%$ Bacto soyton in Jamarin S (artificial seawater, Jamarin Laboratory), $\mathrm{pH}$ 7.5] (Chiura et al. 1988) was used as nutrient medium for the culture of marine strains at $25^{\circ} \mathrm{C}$ and the liquid culture (3 l) was shaken at $120 \mathrm{rpm}$. LB [Luria Bertani medium: $1 \%$ polypeptone, $0.5 \%$ yeast extract, $1 \%$ sodium chloride in distilled and deionized water (DDW), pH 7.5] (Sambrook et al. 1989) was used to culture Escherichia coli at $30^{\circ} \mathrm{C}$ and liquid cultures were shaken at $120 \mathrm{rpm}$. Bacteria were grown in the dark during experiments to eliminate any light effects.

Selection medium. For selection of VLP-mediated gene transferred Escherichia coli, minimal media (MM) after Davis (in Difco Manual 1985) supplemented with 3 out of 4 amino acids, namely, leucine, proline, histidine, and arginine were used. MM contained 10\% Davis salt solution $\left[0.2 \% \mathrm{KH}_{2} \mathrm{PO}_{4}, 0.7 \% \mathrm{~K}_{2} \mathrm{HPO}_{4}, 0.1 \%\right.$ $\left(\mathrm{NH}_{4}\right)_{2} \mathrm{SO}_{4}, 0.05 \%$ sodium citrate], $0.01 \% \mathrm{MgSO}_{4}, 0.2 \%$ glucose and $1 \mathrm{mg} \mathrm{l}^{-1}$ thiamine. Amino acids of $20 \mathrm{mg} \mathrm{l}^{-1}$ each were supplemented to the selection media.

Preparation of VLPs. VLPs were isolated and purified as previously described from prolonged culture broth of respective strains (Chiura et al. 1995). In brief, culture filtrate was obtained by centrifugation $(7500 \times g$, 40 min) from $100 \mathrm{~h}$ cultured marine strains in PPES II broth at $25^{\circ} \mathrm{C}$ with shaking. Cell washing was done with $0.5 \mathrm{M} \mathrm{NaCl}$ and $1 \mathrm{mM}$ EDTA (Chiura et al. 1995) by centrifugation $(7500 \times g, 40 \mathrm{~min})$. DNase I, RNase A and phenylmethylsulfonyl fluoride (PMSF) (Sigma, USA) were added to the culture filtrate as $1 \mathrm{\mu g} \mathrm{ml}^{-1}$, $1 \mu \mathrm{g} \mathrm{ml}^{-1}$ and $100 \mathrm{nM}$ and kept at $25^{\circ} \mathrm{C}$ overnight. The culture filtrate was then passed through a $0.2 \mu \mathrm{m}$ membrane filter (Millipore, USA) and concentrated to ca $50 \mathrm{ml}$ using a Minitan S (Millipore, USA) system with $10 \mathrm{kDa}$ cut-off filter.

The concentrated culture filtrate was filtered again through $0.45 \mu \mathrm{m}$ and $0.22 \mu \mathrm{m}$ membrane filters, then centrifuged at $80000 \times g$ for 30 min using a Beckman Preparative Ultracentrifuge L8M with 55.2Ti rotor to pellet VLPs. The obtained pellet was resuspended in $100 \mu \mathrm{l}$ of TBT buffer $(100 \mathrm{mM}$ Tris- $\mathrm{HCl}, 100 \mathrm{mM} \mathrm{NaCl}$, and $10 \mathrm{mM} \mathrm{MgCl}_{2}$ ) and purified by $\mathrm{CsCl}$-density gradient ultracentrifugation (Davis et al. 1980).

Enumeration of cells and VLPs. Prior to the harvest of the culture filtrate, a viable count of cells and number of VLPs was investigated. A viable count of cells was determined on PPES II solid medium at $25^{\circ} \mathrm{C}$. The number of VLPs was determined according to Børsheim et al. (1990) for culture filtrates with $0.22 \mu \mathrm{m}$ membrane (Millex-GS, Millipore, USA) filtration, because the marine strains used as VLP sources secreted a murein-like substance during culture. Since this murein-like substance could not be removed even with brief centrifugation and dilution, direct counts of VLPs from culture broth on the electronmicroscopic grid were impractical. Therefore enumeration was conducted for the culture filtrate. Following staining for $30 \mathrm{~s}$ with $2 \%$ uranyl acetate, grids were examined at $\times 75000$ at an accelerating voltage of $60 \mathrm{kV}$ with a JEM-1200EX electron microscope (JEOL Inc., Japan). Eye fields were randomly selected and counted until the total count exceeded 250 VLPs. The size of the eye field was used to keep track of the area.

VLP-mediated gene transfer protocol to Escherichia coli. In order to ensure reproducible physiological condition of the recipient $E$. coli $\mathrm{AB} 1157$, the bacterium was cultured at $30^{\circ} \mathrm{C}$ by shaking $(120 \mathrm{rpm})$ until a cell density of $4 \times 10^{8} \mathrm{cfu} \mathrm{\textrm {ml } ^ { - 1 }}$ was attained, then glycerin (Merck, Germany) was added to the culture to a final concentration of $7 \%$, and the culture dispensed as $2 \mathrm{ml}$ aliquots. Seed culture aliquots were frozen immediately in liquid nitrogen and kept at $-85^{\circ} \mathrm{C}$ until use. For gene transfer experiments, a $2 \mathrm{ml}$ aliquot of frozen seed culture was mixed with $3 \mathrm{ml}$ of fresh LB broth in an L-shaped test tube and grown to mid-exponential phase at $30^{\circ} \mathrm{C}$ with shaking, then centrifuged at $5000 \times g$ in a Kubota RT20000 refrigerated centrifuge using an RA3 rotor (Kubota, Japan) and suspended in $5 \mathrm{ml}$ of TBT buffer. The cell suspension thus obtained gave a viable count of ca $2 \times 10^{8}$ colony forming units (cfu) $\mathrm{ml}^{-1}$. One $\mathrm{ml}$ of this suspen- 
sion was mixed with a VLP specimen to obtain a multiplicity of infection (MOI) of 0.1 . The tube was left undisturbed at $30^{\circ} \mathrm{C}$ for $15 \mathrm{~min}$. After incubation, cells were washed with Davis salt solution and finally suspended in $1 \mathrm{ml}$ of the same solution. This mixture was plated in triplicate on appropriate selection media and incubated for $2 \mathrm{~d}$ at $30^{\circ} \mathrm{C}$. Five controls were included: (1) recipient cells with TBT buffer instead of VLPs to determine spontaneous revertant rate; (2) ultraviolet light (UV)-inactivated VLPs and recipient cells; $(3,4)$ VLPs with/without UV inactivation with no added recipient cells; and (5) contained VLPs, recipient cells and DNase $\mathrm{I}\left(10 \mu \mathrm{g} \mathrm{ml}^{-1}\right)$ to exclude the possibility of transformation. For UV inactivation, a VLP suspension was placed in a Petri dish, filled with water to $2 \mathrm{~mm}$, and the suspension of VLPs was irradiated for $15 \mathrm{~min}$ with a $15 \mathrm{~W}$ UV sterilizing lamp (Hitachi, Japan) from $30 \mathrm{~cm}$. As a reference for UV inactivation, coliphage $\mathrm{T} 4$ was treated under the same conditions, and as a result the plaque forming ability of T4 was reduced by 7 orders of magnitude.

\section{RESULTS AND DISCUSSION}

\section{Bacterial growth and VLP production}

All 5 marine strains (Q10MB) spontaneously released VLPs into the culture medium after prolonged incubation. None of the VLPs obtained in the present study gave plaques on lawns of both the original host bacteria and recipient Escherichia coli. VLP and cell numbers and ratios after $100 \mathrm{~h}$ culture are summarized in Table 2. In descending order, VLP:host bacteria ratios were: Alc 233, 1.54; Alc 252, 1.26; Alc 096, 1.06; Flavobacterium sp. I1604, 0.69; and Agrobacterium kieliense, 0.06 . Although direct comparison of these ratios with values from the natural water column is not appropriate, it should be pointed out that the highest ratio was far smaller than values found in the natural aquatic environment (Bergh et al. 1989, Børsheim et al. 1990, Proctor \& Fuhrman 1990, Hara et al. 1991, Hennes \& Suttle 1995, Mathias et al. 1995). Incidentally, spontaneously induced coliphage $\lambda$ allowed one to estimate a virus-host ratio of 0.005 (Birge 1994). Phage $M u$ lysogens release phages spontaneously at a low level virus-host ratio of 0.0001 but are not induced by treatment with UV or other DNA-damaging agents (Howe \& Bade 1975 , Ljungquest \& Bukhari 1977, Howe 1987). Although the values observed in this study were biased due to filtration, marine strains have shown considerably high rates of spontaneous VLP induction.

Lytic growth of lysogenized bacteria in nature would be induced by a factor such as UV light or nutrient depletion (Ackermann \& DuBow 1987). Though the influence of UV-visual light irradiation on the lysogens' induction has been reported to be small (Wilcox \& Fuhrman 1994), bacteria were grown in the dark during experiments to eliminate any light effects. Almost all nutrient in the broth (dissolved total carbohydrate and protein content) was consumed by the bacteria at about $18 \mathrm{~h}$ after starting the culture (data not shown), so it is likely that initiation of a starvation state of the host triggers VLP production. In certain aquatic environments, as many as $45 \%$ of isolates were lysogens (Ogunseitan et al. 1990, Miller et al. 1992). In addition, more than $90 \%$ of natural isolates of Salmonella have been reported to be lysogenized (Schicklmaier \& Schmieger 1995). Marine strains used in this study are most probably lysogens.

The spontaneous release of VLPs has been reported from archaebacteria, Methanococcus voltae (Wood et al. 1989), Sulfolobus (Zilling et al. 1988), and the photosynthetic bacterium Rhodopseudomonas capsulata (Wall et al. 1975, Solioz \& Marrs 1977), but the phenomenon has not been considered ubiquitous in nature. However, preliminary experiments to examine spontaneous VLP production using marine isolates such as Alcaligenes (1 strain), Flavobacterium (2 strains), Oceanospillirum (1 strain), Vibrio (3 strains) and 6 unidentified strains showed positive results (Chiura unpubl. data). All of these strains were isolated from an ordinary, not extreme, marine environment (Table 1). Recently, high occurrence of spontaneously induced temperate phages were found in natural isolates of Salmonella with a high generalized transducing trait, which suggested a high rate of existence of spontaneously induced phage production and higher potential of phage-mediated gene transfer in a natural habitat (Schicklmaier \& Schmieger 1995). Therefore, spontaneous production of VLP might be a common feature shared among certain marine bacteria, at least in the strains of Q10MB. Such VLP-host coexistence allows us to speculate that naturally occurring gene exchange processes may occur in the marine microbial community.

Table 2. VLP and cell number at $100 \mathrm{~h}$ culture with specific reference to VLP:host bacteria ratio

\begin{tabular}{|lccc|}
\hline Strain & Cells ml & VLP ml & VLP:CeII no. \\
\hline $\begin{array}{l}\text { Agrobacterium } \\
\quad \text { kleliense }\end{array}$ & $1.29 \times 10^{10}$ & $7.07 \times 10^{8}$ & 0.055 \\
Alc 096 & $6.69 \times 10^{8}$ & $7.11 \times 10^{8}$ & 1.062 \\
Alc 233 & $2.93 \times 10^{6}$ & $4.51 \times 10^{8}$ & 1.541 \\
Alc 252 & $4.67 \times 10^{9}$ & $5.88 \times 10^{19}$ & 1.260 \\
Flavobacterium & $2.32 \times 10^{9}$ & $1.60 \times 10^{9}$ & 0.689 \\
sp. I1604 & & & \\
\hline
\end{tabular}




\section{Morphology of VLPs}

Characteristic features of obtained VLPs are summarized in Table 3. VLPs from Agrobacterium kieliense were especially characterized for an envelope structure of varying length $(0.8$ to $1.5 \mu \mathrm{m})$ in which 1 to several spherical particles (number of particles inside \pm SD $5.1 \pm 2.8$ particles; examined number of envelopes, $\mathrm{n}=60$ ) were encapsulated (Chiura \& Takagi 1994) Though some eukaryotic viruses, such as the influenza virus, have envelopes, this is not a common feature for prokaryotic viruses. RNA phage 06 of Pseudomonas is a typical example of an encapsulated prokaryotic virus whose particle is incorporated into the recipient cell during infection (Calender 1988). The gene transfer agent (GTA) of Rhodopseudomonas is reported to be encapsulated (Wall et al. 1975, Solioz \& Marrs 1977). Transformasomes from Haemophilus are reported to produce membranous material which is capable of encapsulating exogenous DNA in the surroundings of the cell (Kahn et al. 1983). However nothing is known about the relationship between those reported membranous encapsulated particles and the particles studied in this study.

VLPs from Alc 252 had a short tail (ca $25 \mathrm{~nm}$ ) structure with an ellipsoid head. VLPs of Alc 233 were observed to be icosahedrons. Flavobacterium sp. I1604 gave ellipsoid VLPs (Chiura et al. 1995) and Alc 096 were almost complete spherical particles. In terms of head size, VLPs from Agrobacterium kieliense were classified in the largest category of head size class and VLPs from the other 4 strains were in the most abundant head size class found in the sea, namely 60 to $80 \mathrm{~nm}$ (Børsheim 1993).

\section{VLP-mediated gene transfer experiment to Escherichia coli AB1157}

2,4-Dichlorophenoxyacetic acid utilization (2,4-D) and some chromosomal gene transfer mediated by VLPs derived from Agrobacterium kieliense and Flavobacterium sp. 11604 to recipient Escherichia coli AB1 157 have been demonstrated earlier (Chiura \& Takagi 1994, Chiura et al. 1995). In order to examine the possibility of non-specific VLP-mediated gene transfer, sources of VLPS were extended to other Q10MB, namely Alc 096, Alc 233 and Alc 252. E. coli AB1157 is an auxotrophic mutant with 5 amino acid deficiencies (thr, leu, pro, his, arg), however thr was not used because of its considerably high spontaneous reversion frequency $\left(\sim 10^{-7}\right)$. For the other 4 markers, spontaneous reversion frequencies were found to be below the level of detection. Experimental control of VLP specimens (UV $+/-$ ) plated without adding recipient cells gave no colony formation by plating. DNase I did not affect the gene transfer frequency of any VLP sources. Observed gene transfer frequency with DNase was between 89 and $112 \%$ when compared with the efficiency without DNase, defined as $100 \%$.

Experiments were designed to obtain the expected MOI of 0.1. Observed MOI for each type of VLP were: Agrobacterium kieliense, 0.22; Alc 096, 0.18; Alc 233, 0.14 ; Alc 252, 0.13; and Flavobacterium sp. I1604, 0.12. Efficiency of plating (EOP) after exposure to MOI of 0.1 was used to observe the lethal effect of VLPs to recipient cells. These VLPs showed lethal effects on recipient Escherichia coli by reducing EOP up to 1 order of magnitude. Observed EOP ( \pm SD) for each VLP was as follows: Alc 096, $6.90 \pm 3.1 \times 10^{-2}$; Alc 252, $7.80 \pm 5.2 \times 10^{-2}$; A. kieliense, $1.73 \pm 1.6 \times 10^{-1}$; Flavobacterium sp. I1604, $3.06 \pm 0.33 \times 10^{-1} ;$ and Alc 233,4.03 $\pm 0.45 \times 10^{-1}$. Under the same $\mathrm{MOI}$ and experimental conditions $(\mathrm{MOI}=$ $0.09,30^{\circ} \mathrm{C}, 15 \mathrm{~min}$ adsorption), the lethal effect of coliphage T4 on $E$. coli was $2.44 \times 10^{-5}$ (data not shown). Such low virulence for these VLPs explains why we could not obtain any plaques on the original host strains and $E$. coli. The extent of VLP lethality was comparable to that of piocin $\mathrm{R}$, a bacteriocin produced by Pseudomonas (Amako \& Yasunaka 1979). Although these VLPs had a lower killing rate on $E$. coli than the typical lytic coliphage T4, they showed lethality on bacteria of a different phylogenic group. Hence, they can be taken into account as contributing to the 'phage-induced mortality' in the natural water column (Weinbauer \& Peduzzi 1994, Hennes \& Simon 1995).

Amino acid deficiencies of Escherichia coli were successfully repaired through the gene transfer experiment using VLPs as summarized in Table 4. When UVirradiated VLPs were used as gene transfer mediators,

Table 3. Source strains, average head size in $\mathrm{nm}( \pm \mathrm{SD}, \mathrm{n}$ in parentheses), and presence/absence of envelope and tail of VLPs

\begin{tabular}{|c|c|c|c|}
\hline Source strains of VLP & Head size $\pm S D, n m(n)$ & Envelope / Tail & Source \\
\hline Agrobacterium kieliense & $123.0 \pm 3.9(46)$ & $+/-$ & Chiura \& Takagi (1994) \\
\hline Alc 096 & $55.0 \pm 2.2(18)$ & $-1-$ & This study \\
\hline Alc 233 & $78.6 \pm 8.8 \times 67.3 \pm 6.3(23)$ & $-1-$ & This study \\
\hline Alc 252 & $78.2 \pm 15.7 \times 46.2 \pm 10.2(26)$ & $-1+$ & This study \\
\hline Flavobacterium sp. I 1604 & $85.0 \pm 5.7 \times 70.0 \pm 2.4(54)$ & $-1-$ & Chiura et al. (1995) \\
\hline
\end{tabular}


Table 4. VLP-mediated gene transfer of chromosomal genes. Markers and map location for respective marker on recipient Escherichia coli chromosome. Gene transfer frequencies are expressed per $10^{7}$ VLPs. Values represent mean of triplicate independent experiments ( 3 subsamples per experiment). No gene transfer frequencies were detected from selection plates to which

UV irradiated VLP were used as the VLP sources. DNase I did not affect the gene transfer frequency of any VLP sources

\begin{tabular}{|c|c|c|c|c|c|}
\hline \multirow{2}{*}{$\begin{array}{l}\text { Mark } \\
\text { Source: }\end{array}$} & \multicolumn{5}{|c|}{ Gene transferred cells per $10^{7}$ VLPS } \\
\hline & Agrobacterium kieliense & Alc 252 & Flavobacterium sp. $\mathrm{I} 1604$ & Alc 233 & Alc 096 \\
\hline Leu, 2' & 26364 & 1065 & 1015 & 578 & 481 \\
\hline Pro, $6^{\prime}$ & 21591 & 1438 & 1526 & 996 & 767 \\
\hline His, $44^{\prime}$ & 23500 & 3546 & 1336 & 602 & 358 \\
\hline Arg, $90^{\prime}$ & 10500 & 1164 & 1518 & 760 & 822 \\
\hline
\end{tabular}

no gene transfer frequencies were detected. Although transfer efficiencies for respective markers varied upon applied VLP source, distinctive preference of marker transfer was not observed among markers. At a MOI of 0.1, leu, pro, his and arg markers on the E. coll chromosome exhibited gene transfer frequencies ranging between $2.62 \times 10^{-3}$ and $3.58 \times 10^{-5}$ per VLP. Transducing frequencies of these VLPs were found to be higher by 4 to 7 orders of magnitude than those reported for naturally isolated transducing phages (Saye et al. 1990, Ripp et al. 1994). The marine strains used as VLP source produced a murein-like substance in the broth which was difficult to remove from VLP specimens even after density gradient ultracentrifugation. It is speculated, however, that such a concomitantly isolated murein-like substance together with VLP might play an important role during the gene transfer process. It may stabilize VLP adhesion at a certain receptor site of the recipient cell to promote further gene transfer. Some analogous features of the substance might be membranous materials found during the transformation process in Bacillus (te Riele \& Venema 1984), Haemophilus (Kahn et al. 1983) and Neisseria (Doward et al. 1989).

Consistent gene transfer frequencies for every genetic marker were displayed by VLPs from the same source. Since the loci of employed genetic markers did not come across closely but were dispersed on the Escherichia coli chromosome, it is suggested that all the VLPs examined here carry out generalized gene transfer. As described above, efficiency of lethality was different from source to source and no correlation was found between lethality and gene transfer.

Bacterial conjugation is considered to be the most widespread mechanism of gene exchange in the microbial community (Birge 1986) and this process includes cell to cell contact. Thus, unless the density of the recipient is substantial, one would not expect a high frequency of conjugative gene transfer (Levin \& Lenski 1983). It has been reported that under starvation conditions found in the aquatic habitat the establishment of lysogeny is favoured (Romig \& Brodetsky
1961). Viruses may adsorb to clay minerals and other particles, which appears to protect them against degradation or loss of infectivity from UV exposure over long periods of time (Stozky 1980). An important point to mention is that viruses may persist in the environment under such conditions. This increases the probability of transduction occurring even in environments where the cell density is low. In fact, bacteriophages adsorbed on clay minerals may serve as reservoirs of bacterial DNA in soil and other natural habitats (Stozky 1989). Under the coexistence of lysogenic viruses and bacteria, viruses may be seen as partners of coevolution for the supply of complementary genetic source to the bacterial community (Levin \& Lenski 1983). The packaging of genetic material in a transducing particle probably represents an evolutionary survival mechanism for bacterial genes (Stozky 1989, Veal et al. 1992).

It is generally accepted that the accessible host range for a virus is restricted to the same species, and, even if possible, among the receptors of related species (Calender 1988, Kokjohn 1989, Børsheim 1993, Fuhrman \& Suttle 1993, Birge 1994). The surface features of VLPs might have been one of the factors that determined the uptake of nucleic acids by recipient cells (Hirsch 1990, Dreiseikelmann 1994). Accordingly, virus-mediated gene transfer has not been considered as an important process for redistribution of genetic information. Recently, sufficient evidence has accumulated to exploit the idea that transduction is a meaningful way of gene exchange, being more important in natural ecosystems than has been traditionally envisioned (Novick et al. 1986, Kokjohn 1989, Saye \& Miller 1989, Stozky 1989, Saye et aí. 1990, Miiler et di. 1992, Schickimaier \& Schmieger 1995). The present results imply that spontaneously produced VLPs are important factors for non-specific gene transfer in the marine environment. These VLPS must have interaction with receptors on the recipient bacteria that are not closely related in terms of phylogeny. Hence receptors for such VLPs examined here must share common features in a wide range of different bacterial genera. Phage P1 is also known for its wide host range (Birge 1986, Yarmo- 
linsky \& Sternberg 1988). P1 mutants with extended host range were used to facilitate gene mapping of bacterial hosts, so it is still possible to suspect the existence of viruses (VLPs) with a wide host range in nature (Calender 1988).

This study demonstrated that some marine isolates produce VLPs without artificial induction. These VLPS showed bactericidal effect on Escherichia coli, which belongs to a totally different genus compared to the marine bacterial sources of VLP. Furthermore, such VLPs are capable of intergeneric generalized gene transfer. The importance of this observation is that this is the first demonstration of interspecific and/or intergeneric VLP-mediated gene transfer found among marine bacteria and enteric bacteria. This study implies the existence of spontaneous VLP production mechanism and gene transfer kinetics in the marine environment. The results also suggest that there is a high potential of population control by such VLPs. The source strains of VLPs were not collected from extreme sites, such as hot vents or hypersaline environments, but ordinary marine environments (Table 1). Such facts, together with the results of the present experiment, strongly suggest the prevalent existence of an interspecific and/or intergeneric natural genetic transfer system.

Acknowledgements. The author sincerely thanks M. Akagawa-Matsushita for permission to use unpublished data and for providing marine strains. He also thanks U. Simidu for providing marine strains, K. Kato, B. Velimirov, R. W. Ridge and 3 anonymous reviewers for critical reading, advice, useful comments and suggestions on the manuscript. He is grateful to G. Bratbak, M. Heldal and F. Thingstad for encouragement. Last and certainly not least thanks are given to J. Takagi, $H$. Moribe, D. L. Kato, M. Segawa and other members of the laboratory at ICU and the author's family.

\section{LITERATURE CITED}

Ackermann HW, DuBow MS (1987) Viruses of prokaryotes, Vol 1, General properties of bacteriophages. CRC Press, Boca Raton

Amako K, Yasunaka K (1979) Morphological aspects of bacteriocins. Prot Nucl Acid Enzyme 24:719-726

Ambile Cuevas CF, Chicurel ME (1992) Bacterial plasmid and gene flux. Cell 70:189-199

Bergh Ø, Børsheim KY, Bratbak G, Heldal M (1989) High abundance of viruses found in aquatic environments. Nature 340:467-468

Birge EA (1986) Bacterial and bacteriophage genetics, 2nd edn. Springer-Verlag, New York

Birge EA (1994) Bacterial and bacteriophage genetics, 3rd edn. Springer-Verlag, New York

Børsheim KY (1993) Native marine bacteriophages. FEMS Microbiol Ecol 102:141-159

Børsheim KY, Bratbak G, Heldāl M (1990) Enumeration and biomass estimation of planktonic bacteria and viruses by transmission electron microscopy. Appl Environ Microbiol $56: 352-356$
Brisson-Noel A, Arthur M, Couvalin P (1988) Evidence for natural gene transfer from Gram-positive cocci to Escherichia coli. J Bacteriol 170:1739-1745

Calender R (1988) The bacteriophage, Vols 1 and II. Plenum Press, New York

Chiura HX, Hirota K, Takagi J (1992a) Eubacterial strains sensitive to Aphidicolin are discovered among marine bacteria. J Gen Appl Microbiol 38:87-91

Chiura HX, Kamiyama T, Hirano H, Futagami M, Watahiki M, Kobayashi K. Simidu U, Takagi J (1992b) Purification and characterization of AspMD1, an isoschizomer of Sau3AI, from a marine bacterium, Alcaligenes sp MD1. Nucl Acid Res 20:1996

Chiura HX, Kato K, Takagi J (1995) Phage-like particles released by a marine bacterium. Wiener Mitt Wasser Abwasser Gewässer 128(2):149-157

Chiura H, Noro Y, Kanayama S, Ueda Y, Simidu U, Takagi J (1988) Site specific deoxyribonuclease produced by a marine bacterium, Flavobacterium I 16-04. Agric Biol Chem 52:2107-2109

Chiura HX, Takagi J (1994) Phage-like particles production and gene transfer by marine bacteria. Bull Jap Soc Microb Ecol 9:74-90

Collins M, Jones D (1981) Distribution of isoprenoid quinone structural types in bacteria and their taxonomic implications. Microbiol Rev 45:316-354

Davis WR, Bostein D, Roth JR (1980) A manual for advanced bacterial genetics. Cold Spring Harbor Laboratory, Cold Spring Harbor, NY, p 148-152

De Ley J (1991) The Proteobacteria: ribosomal RNA cistron similarities and bacterial taxonomy. ln: Balows A, Trüper HG, Dwokin M, Harder W, Schleifer KH (eds) The prokaryotes, Vol II, 2nd edn. Springer-Verlag, New York, p 2111-21.40

Difco Manual (1985) 10th edn. Difco Laboratories Inc, Detroit

Don RH, Pemberton JM (1981) Properties of six pesticide degradation plasmids isolated from Alcaligenes paradoxus and Alcaligenes eutrophus. J Bacteriol 45:681-686

Doward DW, Garon CF, Judd RC (1989) Export and intercellular transfer of DNA via membrane blebs of Neisseria gonorrhoeae. J Bacteriol 171:2499-2505

Dreiseikelmann B (1994) Translocation of DNA across bacterial membranes. Microbiol Rev 58:293-316

Fuhrman JA, Suttle CA (1993) Viruses in marine planktonic systems. Oceanography 6:51-63

Gauthier MJ, Breittmayer VA (1990) Gene transfer in marine environments. In: Fry JC, Day MJ (eds) Bacterial genetics in natural environments. Chapman \& Hall, London, p 100-110

Hara S, Terauchi K, Koike I (1991) Abundance of viruses in marine waters: assessment by epifluorescence and transmission electron microscopy. Appl Environ Microbiol 57: $2731-2734$

Heineman JA, Sprague GF Jr (1989) Bacterial conjugative plasmids mobilize DNA transfer between bacteria and yeast. Nature 340:205-209

Hennes KP, Simon M (1995) Significance of bacteriophages for controlling bacterioplankton growth in a mesotrophic lake. Appl Environ Microbiol 61:333-340

Hennes KP, Suttle CA (1995) Direct counts of viruses in natural waters and laboratory cultures by epifluorescence microscopy. Limnol Oceanogr 40:1050-1055

Hirsch PR (1990) Factors limiting gene transfer in bacteria. In Fry JC, Day MJ (eds) Bacterial genetics in natural environments. Chapman \& Hall, London, p 31-40

Howe MM (1987) Phage Mu: an overview. In: Symonds $\mathrm{N}$, Toussaint A, Van De Putte P, Howe MM (eds) Phage Mu. 
Cold Spring Harbor Laboratory, Cold Spring Harbor, NY, p 25-39

Howe MM, Bade EG (1975) Molecular biology of bacteriophage Mu. Science 190:624-632

Kahn MG, Barany F, Smith HO (1983) Transformasomes: specialized membranous structures that protect DNA during Haemophilus transformation. Proc Natl Acad Sci 80: 6927-6931

Kokjohn TA (1989) Transduction: mechanism and potential for gene transfer in the environment. In: Levy SB, Miller RV (eds) Gene transfer in the environment. MacGrawHill, New York, p 73-97

Levin BR, Lenski RE (1983) Coevolution in bacteria and their viruses and plasmids. In: Futuima DJ, Slatkin $M$ (eds) Coevolution. Sinauer, Sunderland, MA, p 99-127

Ljungquest E, Bukhari AI (1977) State of prophage Mu DNA upon induction. Proc Natl Acad Sci 74:3143-3147

Lorenz MG, Wackernagel W (1994) Bacterial gene transfer by natural genetic transformation in the environment. Microbiol Rev 58:293-316

Maruyama A, Oda M, Higashihara T (1993) Abundance of virus-sized non-DNase digestible DNA (coated DNA) in eutrophic seawater. Appl Environ Microbiol 59: $712-717$

Mathias CB, Kirschner AKT, Velimirov B (1995) Seasonal variations of virus abundance and viral control of the bacterial production in a backwater system of Danube river. Appl Environ Microbiol 61:3734-3740

Mazodier P, Davies J (1991) Gene transfer between distantly related bacteria. Annu Rev Genet 25:147-171

Miller RV, Ripp S, Relicon J, Ogunseitan OA, Kokjohn TA (1992) Virus-mediated gene transfer in freshwater environment. In: Gauthier MJ (ed) Gene transfers and environment. Springer-Verlag, Berlin, p 51-62

Miller RV, Sayler GS (1992) Bacteriophage-host interactions in aquatic systems. In: Wellington EMH, Van Elsas JD (eds) Genetic interactions among microorganisms in the natural. environment. Pergamon Press, Oxford, p 176-193

Nagasaki K, Ando M, Imai I, Itakura S, Ishida Y (1993) Viruslike particles in an apochlorotic flagellate in Hiroshima Bay, Japan. Mar Ecol Prog Ser 96:307-310

Novick RP, Edelman I, Lofdahl S (1986) Small Staphylococcus aureus plasmids are transduced as linear multimers that are formed and resolved by replicative process. J Molec Biol 192:209-220

Ogunseitan OA, Sayler GS, Miller RV (1990) Dynamic interactions of $P$ seudomonas aeruginosa and bacteriophages in lake water. Microb Ecol 19:171-185

Paul JH, Rose JB, Jiang SC, Kellogg CA, Dickson L (1993) Distribution of viral abundance in the reef environment of Key Largo, Florida. Appl Environ Microbiol 59:718-724

Proctor LM, Fuhrman JA (1990) Viral mortality of marine bacteria and cyanobacteria. Nature 343:60-62

Reiter WD, Palm P, Yeats S, Zilling W (1987) Gene expression in archaebacteria: physical mapping of constitutive and UV-inducible transcripts from the Sulfolobus virus-like particle SSV1. Mol Gen Genet 209:270-275

Ripp S, Ogunseitan OA, Miller RV (1994) Transduction of a freshwater microbial community by a new Pseudomonas aeruginosa generalized transducing phage, UT1 Molec Ecol 3:121-126

Romig WR, Brodetsky AM (1961) Isolation and preliminary characterization bacteriophages of Bacillus subtilis. J Bacteriol 82:135-141

Rüger H, Höfle MG (1992) Marine star-shaped-aggregateforming bacteria: Agrobacterium atlanticum sp. nov.;
Agrobacterium meteori sp. nov.; Agrobacterium ferrugineum sp. nov., nom. rev.; Agrobacterium gelatinovorum sp. nov, nom. rev.; and Agrobacterium stellulatum sp. nov., nom. rev. Int J Syst Bacteriol 42:133-143

Sambrook J, Fritsch EF, Maniatis T (1989) Molecular cloning: a laboratory manual, 2nd edn. Cold Spring Harbor Laboratory Press, Cold Spring Harbor, NY

Saye DJ, Miller RV (1989) The aquatic environment: consideration of horizontal gene transmission in a diversified habitat. In: Levy SB, Miller RV (eds) Gene transfer in the environment, MacGraw-Hill, New York, p 223-259

Saye DJ, Ogunseitan OA, Sayler GS, Miller RV (1990) Transduction of linked chromosomal genes between Pseudomonas aeruginosa during incubation in situ in a freshwater habitat. Appl Environ Microbiol 56:140-145

Schafer A, Kalinowski J, Simon R, Seep Feldhaus AH, Puhler A (1990) High-frequency conjugal plasmid transfer from Gram-negative Escherichia coli to various Gram-positive coryneform bacteria. J Bacteriol 172:1663-1666

Schickimaier $P$, Schmieger H (1995) Frequency of generalized transducing phages in natural isolates of the Salmonella typhimurium complex. Appl Environ Microbiol 61: $1637-1640$

Schleper C, Kubo K, Zilling W (1992) The particle SSV1 from the extremely thermophilic archaeon Sulfolobus is a virus: demonstration of infectivity and of transfection with viral DNA. Proc Natl Acad Sci 89:7645-7649

Shaefer R, Hinnen R, Franklin RM (1974) Bacteriophage of Halobacterium salinarium. Nature 243:681-683

Sikorski RS, Michaud W, Levin HL, Boeke JD, Hieter P (1990) Trans-kingdom promiscuity. Nature 345:581-582

Solioz M, Marrs B (1977) The gene transfer agent of Rhodopseudomonas capsulata, purification and characterization of its nucleic acid. Arch Biochem Biophys 181:300-307

Stachel SE, Timmerman B, Zambryski P (1986) Generation of single-stranded T-DNA molecules during the initial stages of T-DNA transfer from Agrobacterium tumefaciens to plant cells. Nature 322:706-712

Stozky G (1980) Surface interactions between clay minerals and microbes, viruses and soluble organic and probable importance of these interactions to the ecology of microbes in soil. In: Berkeley RC, Lynch JM, Mellind J, Rutter PR, Vincent $B$ (eds) Microbial adhesion to surfaces. Horwood, Chichester, p 231-249

Stozky G (1989) Gene transfer among bacteria in soil. In: Levy $\mathrm{SB}$, Miller RV (eds) Gene transfer in the environment. MacGraw-Hill, New York, p 165-222

Streips UN, Yasbin RE (eds) (1991) Mordan microbial genetics. Wiley-Liss, New York

Suttle CA, Chan AM (1994) Dynamics and distribution of cyanophages and their effect on marine Synechococcus spp. Appl Environ Microbiol 60:3167-3174

Suttle CA, Chan AM, Cottrell MT (1990) Infection of phytoplankton by viruses and reduction of primary productivity. Nature 347:467-469

te Riele HPJ, Venema $G$ (1984) Molecular fate of heterologous bacterial DNA in competent Bacillus subtilis: further characterization of unstable association between donor and recipient DNA and the involvement of the cellular membrane. Mol Gen Genet 195:200-208

Veal DA, Stokes HW, Daggard G (1992) Genetic exchange in natural microbial communities. In: Marshall $\mathrm{KC}$ (ed) Advances in microbial ecology, Vol 12. Plenum Press, New York, p 35-50

Wall JD, Weaver PF, Gest H (1975) Gene transfer agents, bacteriophages, and bacteriocins of Rhodopseudomonas capsulata. Arch Microbiol 105:217-224 
Weinbauer MG, Peduzzi P (1994) Frequency, size and distribution of bacteriophages in different marine bacterial morphotypes. Mar Ecol Prog Ser 108:11-20

Wilcox RM, Fuhrman JA (1994) Bacterial viruses in coastal water: lytic rather than lysogenic production. Mar Ecol Prog Ser 114:35-45

Wommack KE, Hill RT, Kessel M, Russek-Cohen E, Colwell R (1992) Distribution of viruses in the Chesapeake Bay. Appl Environ Microbiol 58: 2965-2970

Wood AG, Whiteman WB, Konisky J (1989) Isolation and characterization of an archaebacterial virus-like particle from Methanococcus voltae A3. J Bacteriol 171: 93-98

Responsible Subject Editor: G. Bratbak, Bergen, Norway
Yarmolinsky MB, Sternberg $N$ (1988) Bacteriophage P1. In: Calender R (ed) The bacteriophage, Vol I. Plenum Press, New York, p 291-438

Yokota A, Akagawa-Matsushita M, Hiraishi A, Katayama Y, Urakami T, Yamasato K (1992) Distribution of quinone system in microorganisms: Gram-negative eubacteria. Bull Japn Fed Cult Coll 8:136-171

Zambryski P, Tempe J, Schell J (1989) Transfer and function of T-DNA genes from Agrobacterium Ti and Ri plasmids in plants. Cell 56:193-201

Zilling W, Reiter WD, Palm P, Gropp F, Neumann H, Rettenberger $M$ (1988) Viruses of archaebacteria. In: Calender R (ed) The bacteriophage, Vol 1. Plenum Press, New York, p 511-558

Manuscript received: October 4, 1996

Revised version accepted: April 8, 1997 